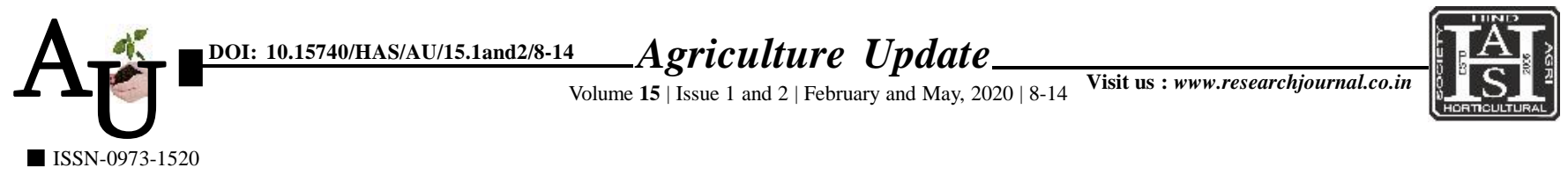

\title{
Research Article: Relational analysis of MGNREGA beneficiaries with socio-economic impact of MGNREGA
}

\author{
V.G. Dhulgand and R.P. Kadam
}

Article Chronicle: Received : 13.01.2020;

Revised :

24.03.2020;

Accepted :

02.04.2020

KeY Words:

Profile analysis, MGNREGA

beneficiaries, Relational analysis, Multiple regression
SUMMARY : The present study was conducted purposively in Aurangabad, Nanded, Beed and Jalna district of the Marathwada region of Maharashtra state during the year 2017-2018. From this four district eight tahsils were selected purposively. From each selected taluka two villages were selected purposively for the study. Fifteen beneficiaries of MGNREGA were selected randomly from each selected villages. Thus, comprising total 240 beneficiaries were selected from Marathwada region for research study. Majority (52.08\%) of the MGNREGA beneficiaries were middle aged, 28.75 per cent educated upto primary school level, $(40.84 \%)$ were found lower category, more than two third (66.25\%) of them having medium family size and 34.16 per cent of them having small size of land holding. It was observed that, more than half $(56.67 \%)$ of them having farming as main occupation, majority $(53.75 \%)$ of them having medium annual income, 57.09 per cent were found joint family, nearly half $(49.17 \%)$ of them having medium social participation, less than half $(46.66 \%)$ of them having medium source of information, 59.58 per cent of them having medium level of extension contact and 45.41 per cent of them having medium level of economic motivation. It was observed from that the independents variables namely age, education, occupation, annual income, family type, social participation, sources of information, extension contact and economic motivation were positively and significantly related with overall impact of MGNREGA scheme. However, category, family size and land holding could not establish any relationship with overall impact of MGNREGA scheme. It was found that co-efficient of determination $\left(\mathrm{R}^{2}\right)$ of the independent variables was 0.685 . It means that 68.50 per cent of total variation in the overall impact of MGNREGA on its beneficiaries was explained by the selected 12 independent variables. The unexplained variation may be due to the factors not included in the study.

How to cite this article : Dhulgand, V.G. and Kadam, R.P. (2020). Relational analysis of MGNREGA beneficiaries with socio-economic impact of MGNREGA. Agric. Update, 15(1 and 2): 8-14; DOI : 10.15740/HAS/AU/15.1and2/ 8-14. Copyright@ 2020: Hind Agri-Horticultural Society.
Author for correspondence:

V.G. Dhulgand Department of Extension Education, Vasantrao Naik Marathwada Krishi

Vidyapeeth, Parbhani (M.S.) India

Email: vgdhulgand91@ gmail.com

See end of the article for authors' affiliations 